\title{
Correction: Travel time and perinatal mortality after emergency caesarean sections: an evaluation of the 2-hour proximity indicator in sierra leone
}

van Duinen AJ, Adde HA, Fredin O, et al. Travel time and perinatal mortality after emergency caesarean sections: an evaluation of the 2-hour proximity indicator in Sierra Leone. BMJ Global Health 2020; 5: e003943. doi: 10.1136/bmjgh-2020-003943.

This article has been corrected since it was published online. Tables 1 and 2 which were missing have been reinstated in the paper.

Open access This is an open access article distributed in accordance with the Creative Commons Attribution Non Commercial (CC BY-NC 4.0) license, which permits others to distribute, remix, adapt, build upon this work non-commercially, and license their derivative works on different terms, provided the original work is properly cited, appropriate credit is given, any changes made indicated, and the use is non-commercial. See: http://creativecommons.org/licenses/by-nc/4.0/.

(C) Author(s) (or their employer(s)) 2021. Re-use permitted under CC BY-NC. No commercial re-use. See rights and permissions. Published by BMJ.

BMJ Global Health 2021;6:e03943corr1. doi:10.1136/bmjgh-2020-003943corr1

(D) Check for updates 